\title{
Enacting Classroom Inquiry: Theorizing Teachers' Conceptions of Science Teaching
}

\author{
SCOTT McDONALD \\ Department of Curriculum \& Instruction, Pennsylvania State University, \\ University Park, PA 16802, USA \\ NANCY BUTLER SONGER \\ School of Education, University of Michigan, 610 E. University Avenue, Ann Arbor, \\ MI 48109, USA
}

Received 8 October 2007; revised 30 March 2008, 23 April 2008; accepted 5 May 2008

DOI 10.1002/sce.20293

Published online 11 September 2008 in Wiley InterScience (www.interscience.wiley.com).

\begin{abstract}
Translating written curricular materials into rich, complex, learning environments is an undertheorized area in science education. This study examines two critical cases of teachers enacting a technology-rich curriculum focused on the development of complex reasoning around biodiversity for fifth graders. Two elements emerged that significantly impact teacher enactment - their conceptions of authenticity (authentic learning/authentic science) and their view of science (descriptive/inferential). The results suggest that disentangling the common conflation of these two elements supports a broader definition of inquiry science teaching that is more sensitive to context and individual teacher enactment. (C) 2008 Wiley Periodicals, Inc. Sci Ed 92:973-993, 2008
\end{abstract}

\section{INTRODUCTION}

The National Research Council (NRC; 1996) and the American Association for the Advancement of Science (AAAS; 1993) have called for classroom science to be more inquiry based. Curricular designers have created curricula to specifically address the complexities of engaging students in classroom inquiry science (e.g., Bell \& Linn, 2000; Blumenfeld, Fishman, Krajcik, Marx, \& Soloway, 2000; Edelson, Gordin, \& Pea, 1999; Krajcik et al., 1998; Reiser et al., 2001; Songer, 1996; Songer, Lee, \& Kam, 2002). However, ambiguity remains as to what constitutes classroom science inquiry teaching and how it differs from inquiry as engaged in by scientists (e.g., Abd-el-Khalick et al., 2004). Part of the ambiguity arises out of the process of teacher enactment ${ }^{1}$ of curricula; teachers are asked to take a

Correspondence to: Scott McDonald; e-mail: smcdonald@psu.edu

${ }^{1}$ Enactment is often used in place of implementation in teacher education literature to emphasize the fundamental interpretive nature of teaching (e.g., Borko, 2004).

(C) 2008 Wiley Periodicals, Inc. 
curriculum designed to foster inquiry in a classroom setting and make it a part of their real practice with real students. Richardson (2002) suggests this interpretive process of curricular enactment, the physical translation of theory into practice, is not well understood or theorized and that "a theory of teaching focused on the act of teaching" (p. 3) must be developed. In science education, this theory of teaching must necessarily be grounded in the conceptions of inquiry science teaching put forward by the NRC standards and AAAS benchmarks. This study attempts to contribute to a nascent theory of classroom inquiry science teaching by generating theoretical elements from critical case studies of teacher enactment of inquiry-fostering curricula.

Science education researchers interested in teacher enactment are beginning to examine how research-based science materials get taken up and enacted by teachers (Crawford, 2000; Keys \& Bryan, 2001; Roth, 1995; Tabak, 2002). Research with teachers in classrooms will help illuminate excellent pedagogy in a variety of contexts and constraints (Songer, Lee, \& McDonald, 2003). Most research on curricular enactment focuses on comparing classroom teaching to either curricular documents or to standards and benchmarks (e.g., NRC or AAAS) looking for fidelity of implementation. This study attempts to reverse the focus on curricula and begins instead with classroom practice to ground theoretical constructs that can be used to characterize classroom inquiry science teaching.

Richardson (2002) is not explicit about the nature of the theory of teaching she describes, but she does indicate it begins with examples of teaching to develop theory. On the basis of this, we approached our effort to contribute to a theory of inquiry science teaching by choosing critical cases of teachers' enactment. Cobb and his colleagues (e.g., Cobb, McClain, Lamberg, \& Dean, 2003; McClain, 2002) have approached this type of work through design research by studying one enactment of mathematics curricula in a classroom with a number of embedded researchers. The team of researchers and teachers meet regularly to both plan the trajectory of instruction and analyze the wealth of data collected. Their specific goal was to develop "an empirically grounded theory on how the intervention works" (Gravemeijer \& Cobb, 2006, p. 18). The "intervention" described by Cobb and his colleagues is not a static, a priori curricula, but a dynamically evolving series of classroom interactions. While our study examines the evolution of an enactment, it does not use the same design-based research approach to the intervention.

While not engaging in design-based research around the BioKIDS curriculum, this research does explicitly set out to theorize teaching in context. There is little science education research that focuses on theorizing inquiry science teaching. One example, Polman's (2000) work, a case study of a teacher engaged in classroom inquiry science, does extract generalizations from a teacher's enactment. The study is of a teacher developing his own inquiry science curricula, and the results are framed in terms of helping designers think about the development of inquiry science curricula and technological tools. It was not the explicit goal of this study, but his work contributes potential elements to a theory of teaching; however, the results are framed in terms of curricular design.

Unlike Polman's case study, this research specifically shifts the focus from the design and implementation of curricula to the teacher and their interpretation and enactment of the pedagogy. We used cases in an attempt to understand critical enactment differences and the underlying theoretical differences they represent. We examined science teaching as a research-based component supporting a theory of science teaching grounded in classroom practice. The overall question guiding the study was

What different conceptions of classroom science emerge through teachers' enactment of a technology-rich, science curricula designed to be inquiry fostering? 
Two teachers enacting an inquiry-fostering, technology-rich science curriculum were chosen for their substantial contextual and philosophical differences. The study was designed to illuminate theoretical elements useful for teachers and researchers to understand how multiple enactments of inquiry science can promote complex reasoning (Songer et al., 2003). In addition, this study can contribute to developing a more nuanced view of how inquiry can be described, supported, and theorized in a variety of contexts.

\section{TEACHERS' TALK}

This work and the curricula the teachers' enact are based on social constructivist models of teaching and learning (Vygotsky, 1978), which presumes that learning is situated (Lave \& Wenger, 1991), distributed (Pea, 1993), and social (Palinscar, 1998). Specifically, this study approaches classrooms from a community of learners model (Brown et al., 1993), which suggests that students should be learning about science while engaging in the doing of science. In a community of learners, students work together not just to understand science content, but to understand the structure of science as a discipline. Communityoriented classrooms shift the teacher into the role of facilitator or "more knowledgeable other" (Palinscar, Magnusson, Marano, Ford, \& Brown, 1998; Putnam \& Borko, 2000). To move classroom pedagogy toward this community model, science teachers must support students as they engage in knowledge construction about science, something they often find difficult (Davis, 2003). The focus of analysis for understanding a community of learners is the activity of the community, and in particular the discourse of the classroom. The explicit and implicit conceptualizing teachers do about science and pedagogy sets the foundation for the classroom discourse, and by extension students' learning.

Adopting the lens of communities of practitioners when understanding educational contexts is an emergent theme in research studies, and yet the focus and approach to this type of work varies. Cobb and his colleagues (Cobb et al., 2003; Cobb, Stephan, McClain, \& Gravemeijer, 2001) studied the development of classroom norms in mathematics over time. Ball and Bass (2000) investigated how students developed a classroom knowledge base and used the knowledge as a basis for mathematics discourse. Roth and Lawless (2002) found that focusing on discourse patterns helps students become competent with writing and abstract symbols in science. This investigation focuses on how teachers structure the classroom-learning environment and how this exemplifies particular conceptions of the tools and discourse of science.

\section{DESIGN AND PROCEDURE}

\section{Context}

Extensive data were collected on two teachers during their enactment of BioKIDS: Kids' Inquiry into Diverse Species, an 8-week, technology-rich curriculum focused on the development of complex reasoning in biodiversity for fifth graders (Songer, 2006). Through in-depth examinations of the scientific concepts of biodiversity, food webs, and animal interactions, the curricular activities were designed to involve students in technologysupported field data collection, in-class observation of animal specimens, and research on local animal species. As complex scientific reasoning was a major goal, the curricular activities were specifically designed to scaffold students' development of scientific claims and explanations based on evidence (Songer et al., 2003). The activities use local animal distribution data gathered in their schoolyard by students using personal digital assistants (PDAs). Students also gathered information about local animals using a Web-based resource 
of taxonomically arranged species accounts called the Critter Catalog (Dewey, Hammond, Espinosa, Parr, \& Jones, 2005). The PDA-gathered animal data were combined with the species account information to support students' learning around biodiversity.

\section{Teachers}

Two teachers enacting the BioKIDS program were chosen for this study to represent critical cases (Moschkovich \& Brenner, 2000). The teachers were chosen to provide critical case differences in terms of context and likely enactment. Both teachers were prior participants in the research project and were teaching fifth-grade students. One teacher was in a self-contained suburban classroom and had little formal science content training. The second teacher taught multiple sections in a science-specific classroom in an urban district and had a strong science content background.

The first teacher, Mr. Denny, was in his mid-30s and had been an elementary school teacher for 12 years. He taught a mixed fifth- and sixth-grade class in a midsized, welleducated, affluent suburban town. Mr. Denny's school was a K-8 school based on the open philosophy of education (Combs, 1991), which is progressive and student centered. Mr. Denny had 28 students in his class, 13 sixth graders, and 15 fifth graders. There were 11 girls and 17 boys. The school was located a short (10 minute) walk from a 52-acre undeveloped park (Riley Park), which Mr. Denny used as a field site for data collection during the program. Mr. Denny was an English major as an undergraduate, and had little background or formal training in science. Mr. Denny's classroom had six computers, four older and two newer Macintosh computers with Internet connections via the school network. In addition, Mr. Denny had access to a computer lab in a classroom next to his with 30 newer Macintosh computers with Internet access.

The second teacher, Ms. Brooks, was also in her mid-30s and had been a middle school teacher for 10 years. Ms. Brooks was a science teacher with five science classes a day, two with fifth-grade students and three with sixth-grade students. She taught in an urban charter school for grades four through eight emphasizing mathematics, science, and technology. One class was chosen for observation based on convenience, which had 29 fifth-grade students: 14 boys and 15 girls. The school was located on a busy urban street with a small (approximately 1.5 acre) fenced-in playground behind the school. One area of the playground contained a play structure with woodchips beneath it, another section had a basketball court, and there was an area of open grass at the back of the playground. There were two large planting boxes between the parking lot and the playground and a small area at the front of the school with grass, flowers, and trees. Ms. Brooks had 30 computers in her room. The machines were approximately 2 years old, with about half functioning at any given time. Often these computers could not connect to the school network for Internet access.

\section{Data Analysis}

Data on teacher enactment were collected over the course of a single enactment of the BioKIDS program. The duration differed between teachers based on local scheduling and constraints, lasting 11 weeks for Mr. Denny's class and 10 weeks for Ms. Brooks's class. Data on each teachers' enactment consisted of (a) interviews recorded with teachers prior to the start and after the completion of the curriculum, (b) classroom enactment recorded by a lavaliere microphone on the teacher for every class session, (c) researcher's fieldnotes from observations of every class session, and (d) informal meetings between the teacher and researcher recorded by audiotape: four for Mr. Denny and seven for Ms. Brooks. 
Data analysis was guided by Miles and Huberman (1984) and broadly characterized as (1) elaboration of fieldnotes, (2) generation of initial codes, (3) transcription to add detail to fieldnotes, (4) coding of fieldnotes/transcription, (5) development of conjectures and modification of codes, (6) testing of conjectures against the corpus of data, (7) general themes developed based on conjectures, (8) detailed narrative written to exemplify themes, and (9) themes revised and clarified with input from teacher participants and other researchers.

Data were coded in units of analysis representing complete ideas ranging in length from a short sentence segment to a short paragraph. More than 2300 units were coded from the transcripts and fieldnotes of 37 days of enactment from both teachers using Hyperresearch ${ }^{\circledR}$ qualitative analysis software. Each unit was coded with at least one code representing the analytical value of that unit. For example, a unit might be coded as representing a teacher's choice about a content goal for the students (e.g., coded as Focus, Content, Biodiversity) or a teachers choice about the use of a particular technology tool to support student activity (e.g., coded as Mean, Technology, CyberTracker). A total of 43 hierarchically organized codes were developed to represent teachers' choices about authenticity, science content, inquiry process, use of technology, and constraints they encountered (see the appendix for complete coding list).

The analysis process consisted of coding of text from transcriptions and fieldnotes as well as writing analytical memos during coding. These memos were used as sources of initial conjectures. Conjectures were tested against other instances of a code in the corpus of data in an effort to find both supporting and disconfirming evidence. As conjectures developed, they were combined with other conjectures as well as instances of codes to create higher order conjectures, based on higher degrees of inference. This process of refinement and testing continued until the researcher determined that conjectures within a case warranted a cross case comparison to flesh out a theme. Themes were then tested against prior conjectures and evidence from specific coded instances (see Figure 1 for an example of theme development). After themes had been generated, vignettes were written for each teacher in an attempt to capture the themes using a condensed form of the original data. These vignettes serve as a theoretical and intentional sampling designed to support and exemplify the analytically developed themes. These vignettes are included below.

\section{VIGNETTES}

To understand the findings from this study, it is important to get a sense of the differences between the two teachers' enactment of the BioKIDS curriculum. The following section presents analytical vignettes for each teacher. The brackets following each direct quote contain one or more codes applied to the instance. These have been included in an effort to clarify the coding and analysis process. The listing of codes in the brackets is not exhaustive, but representative and codes are chosen to support the theoretical elements embodied in the vignettes. The vignettes are organized chronologically with direct quotes linked together with text to create a logical narrative flow. The vignettes are written to highlight the specific data necessary to warrant the analytical elements described in the discussion including both teachers' implicit and explicit conceptualization of science teaching.

Mr. Denny's vignette, the first of the two, exemplifies two key aspects of his enactment: (1) students' are given input and direction in their own investigations and (2) students collect field-based observations including identification of collected organisms. In the second vignette, Ms. Brooks's enactment is exemplified by (1) students' developing scientific process skills similar to those used by scientists studying biodiversity and (2) students developing analytic skills of data collection, data representation, and inference from 


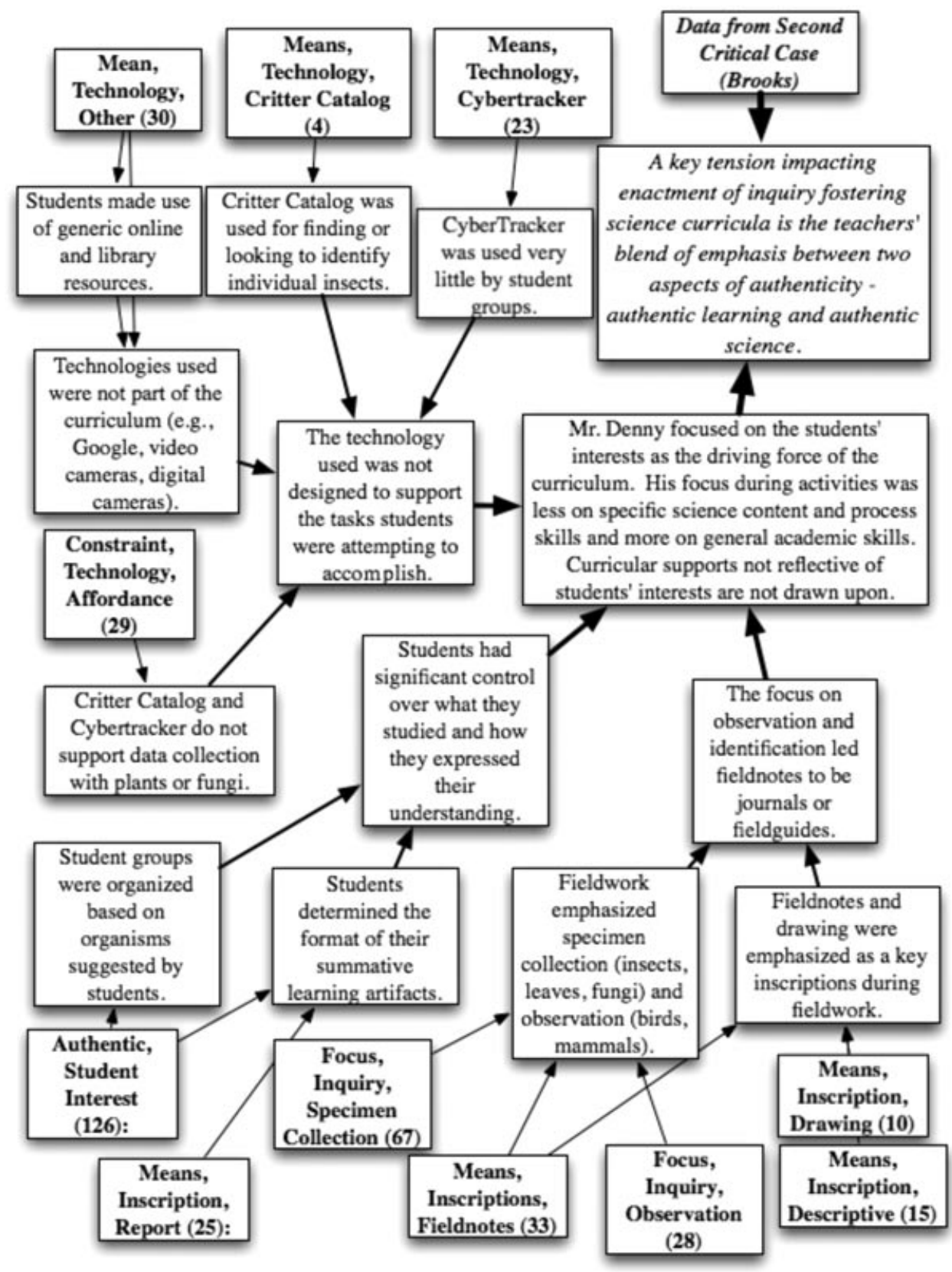

Figure 1. From codes to themes. The figure shows how themes were developed from codes. Codes are in bold and indicate the number of instances of that code for the case in parentheses. Thickness of links indicates level of inference, with thicker meaning high level of inference.

representations. In the vignettes, the use of I and me represents the first author responsible for primary data collection.

\section{Mr. Denny}

Mr. Denny and I met for his initial interview. I asked him about BioKIDS, his plans for this year, and how it would be different from the previous spring. 
I would much rather see the kids, if they're really passionate about one subject or one idea, let them pursue that and through pursuing that they'll learn how to write well and learn how to research, gathering information and then making decisions based on information. [Authentic, Student Interest]

In the previous school year, he and his students participated in the BioKIDS program and agreed to follow the written curriculum closely for purposes of research on curricular supports for claims and evidence (Lee \& Songer, 2003). In the year, the study was completed he was willing to participate with BioKIDS, or more accurately an exploration in biodiversity based on BioKIDS, but wished to have more control to adapt the curriculum to his personal philosophy. He emphasized going out to Riley Park as a study site, and described his hopes to his students during their study of biodiversity in Riley Park:

[I want you to... ] gather information, organize data, make some conclusions based on your data, use technology to help you gather and sort and present data, practice some research skills and certainly in the context of doing all of that you're going to be doing a lot of reading and writing. [Focus, Inquiry, Data Collection; Focus, Inquiry, Inferences]

Mr. Denny started the first day at the front of his room and addressed his students with an overview of their plans:

Today we are going to Riley Park for a BioKIDS experience. Riley Park is going to become like our lab, like you have a science lab upstairs. So, today were going to go there as a class. My expectation is that we just kinda walk around, familiarize ourselves with the park. We have an aerial map of what it looks like. And I would like to get you guys to the point where you just feel comfortable with the main trails in this park. It is not huge, but it is somewhat confusing, because there is a maze of trails in there. My intention is to be out there every Monday for the next seven to eight weeks, alright. [Authentic, Local Site]

He then asked students about vocabulary and defined key terms, specifically biodiversity, abundance, and richness. While talking with his students he wrote key terms on the board.

Mr. Denny told me he sees himself as a facilitator of students' interests. I am interested in how he adapted BioKIDS lesson plans if the enactment is so dependent on students and what they want to learn. How did he organize what students do in the classroom?

I come up with an idea or situation based on what I've heard them express interest in, I'll do some initial organizing and exposure, then I'll turn it over to them, see their reaction and then I'll go from there. That's what my jumping off point is and then I kind of use the kids almost like leap frog. I know after Monday they're going to come back and have ideas about what they're interested in and then my job becomes taking those ideas and helping the kids to formalize them more. [Authentic, Outcome]

On the first day, the students finished their lunch and Mr. Denny called them into the front of the class to go over their goals for their time in Riley Park. During this visit, he did not have them carry anything for recording fieldnotes. However, on returning to the classroom he debriefed their experience and set expectations for the curriculum. Specifically, he brought up the topic of a field notebook they will use later, "These are like reflective journals or maybe what you can think of as a field journal" [Means, Inscriptions, Fieldnotes]. He mentioned the students will use CyberTracker, a tool used by field biologists to support them in collecting fieldnotes in Riley Park. 
OK. Well it's a little more than just using the Palm Pilot, I'm glad you've been exposed to it. . its [CyberTracker] a program on the Palm Pilot that will help you when you're out in the field, out in Riley Park, take useful notes. [Means, Technology, CyberTracker]

The following week as they prepared for their next field site visit, Mr. Denny asked students to move beyond talking about a species or group of animals they are interested in and begin an investigation in biodiversity. To facilitate this, he turned to the list of groups the class has formed based on their interests. Mr. Denny asked everyone to make a choice of which group to join. After students clarified their choices and changed groups, many of the vertebrate groups disappeared from the list. This is likely because Mr. Denny discouraged studying vertebrates as he believed they are difficult to find and count. The final list of groups the children can join includes trees, spiders, insects (or arthropods), fungi, and a group consisting of one student interested in birds.

The following week, September 23, he encouraged students to make more detailed notes about the environment surrounding the specimens they found in the field.

Insect people, I want that you do, when you find an insect, I know like Scott's group did a good job of this. Take some notes about its environment. Where do you find it? On the ground? On the tree? Maybe what kind of tree. Under debris, in the sunshine, OK. [Focus, Inquiry, Observation; Means, Inscriptions, Fieldnotes]

On the third field day, September 30, Mr. Denny started to talk more specifically about making drawings of the animals as a way to gather more information in their fieldnotes. Mr. Denny said that the close examination of the animals will help them identify the animals for later study. The students have one final field site visit on October 7 for a total of 4 days in the field.

After field visits are completed, the class began independent work on their projects. Mr. Denny began class on October 28 by reading through student drafts of project plans designed to represent their learning during the field visits:

[Mr. Denny reading] An orb weaver, Bill and I are planning to do a report on orb weavers. Great. That's, I think Fernando. You guys today can use the computer lab and get on there and use the Critter Catalog. I will pick seven spiders. I will study each of them and then write the basic information about them.” [Means, Technology, Critter Catalog]

I will measure the abundance of box elders and sugar maples and at the end I will compare the numbers and see which has higher abundance. Nice, Henri. [Focus, Inquiry, Data Collection]

A number of students had difficulty writing reports as they did not collect specific data on animals or plants in their fieldnotes. For example, several student groups (e.g., fungi group, spider group, and insect group) are challenged because of the difficulty in making accurate identifications:

If you can't figure out what kind of spider that spider is then you could study another spider. That's fine, OK... The problem is there's so many insects that, arachnids, insects, arthropods, whatever you want to say, that nobody knows them all and I don't know that even Hank [BioKIDS field biologist/entomologist] would know them so you could be doing a, what I'm asking you to do is find a similar spider, get as close as you can and study that. OK, yes and that's fine. You know it's a spider right? You can certainly find a spider that looks similar to it. [Focus, Inquiry, Identification] 
After class, Mr. Denny reflected in an interview about an observation he made this year:

I'm finding. . . that the variety of the ways the information is presented is going to be pretty cool and that level at which there, and. . that level of detail for each project is going to be much deeper and in the end I would like to, to pull them together and maybe focus more. . I I think last year they got a bigger picture idea. This year they're getting more in-depth. .. and I'd like to tie them all in at the end and look more at abundance and richness, you know. If your Cardinal eats beetles and there's no beetles, you know. [Focus, Inquiry, Inference]

As the program continued over the next 2 weeks, the inability of the students to find information on individual animals continued to cause frustration. Most students resort to gathering information at the plant or animal group level rather than individual plant or animal level. Mr. Denny guided them in gathering information through Internet and library resources:

Well I would suggest this, you have, you have some trees that you found, right? You could find information on those, on the Internet. You could look them up in a tree book. I have many, many different books over here on trees. All right. You could write up a report on those. [Means, Inscription, Report]

Throughout the enactment, Mr. Denny continued to act as facilitator and guide to help students work toward a final report on their organism.

All right, well you have box elder, you have sugar maple. You could, if nothing else, you could take this, type it up. Edit it, type it up, OK. How about that, that's something you could work on. [Means, Inscription, Report]

At the end of 10 weeks, the final projects ranged in scope and presentation. They included a fairly detailed map of the trails in Riley Park, a video about fungi found in Riley Park, a Hyperstudio $^{\mathrm{TM}}$ stack with information about funnel-weaving spiders, and a local tree guide including leaf samples. The projects, regardless of medium and type of organism, were descriptive reports on animal or plant groups whose members could be found in Riley Park.

Upon reflection, Mr. Denny's enactment is characterized by his emphasis on observation, identification, and students' personal interests. Students used technology to assist in observations (digital still and video cameras) and information gathering (Web-based resources on organisms found in the field). The project data collection technology, the PDA-based CyberTracker software, was significantly less useful as the software did not support the investigations of plants. As a result, Mr. Denny's chose to forgo the use of PDAs and CyberTracker with his class. Mr. Denny's students generated observational artifacts, such as tree guides and videos about mushrooms. The main focus of the fieldnotes was observation, and students did not view them as data, but more as journals or notebooks. While some of the fieldnotes collected by students had the potential to be used in a more analytical fashion, data for analytical purposes were not an avenue pursued by Mr. Denny.

The second vignette characterizes Ms. Brooks's enactment to provide contrast to Mr. Denny across two key elements of inquiry science teaching. Discussion of the themes cutting across both cases is discussed following Ms. Brooks's vignette. 


\section{Ms. Brooks}

Ms. Brooks and I talked after school the day before she started the curriculum. I asked her about her plans for BioKIDS. She mentioned that she was planning to add an optional activity about connecting biodiversity to a local environmental issue.

I was going to try and find out, and it was something I was thinking about when I was seeing about the brownfields was there's a couple of areas. We've got a couple right around the school over here. I think on the other side of that house there's an empty lot. We could maybe even look into it or we could even compare our schoolyard to that lot. . because the people that live in that house, this year their son is enrolled in our school. [Authentic, Local Issue; Authentic, Local Site]

Brownfields are areas contaminated with commercial or hazardous waste and in urban centers often appear as abandoned lots. They present a significant local problem as they are commonplace, and the city has provided no resources to clean them up. Ms. Brooks felt the connection to a local issue might ground students' learning in something concrete.

Ms. Brooks was interested in her students' learning of science content and reasoning and saw BioKIDS as a way to do that in an interesting and engaging way. She was primarily interested in preparing her students for taking standardized examinations. One of these, the Michigan Educational Assessment Program (MEAP) is a high stakes test linked to school success and reorganization or closure of schools.

So I mean the [Detroit Public Schools] curriculum's all spelled out. I mean as far as the skills we're teaching the standardized tasks so I don't have a whole lot of choice in some of those other matters. You know I'm teaching so that they are successful on the MEAP, and that's it. [Constraint, Standardized Test]

BioKIDS was designed to align with district and state standards, and it focused on similar learning goals. In addition to the content standards, Ms. Brooks also expressed an interest in having students collect and analyze data to improve their reasoning skills.

I think what [the BioKIDS curriculum designers] have going here, the kids really have to think. I mean they're working on the critical thinking skills. They're observing and looking at things more critically and having to analyze it. [Focus, Inquiry, Observation; Focus, Inquiry, Inference]

She mentioned that at a point about halfway through the unit most of the students will be participating in a field experience an hour north of the city. While in the past she has used this trip to allow inner city students to experience time outside the city, she has never viewed it as a science-learning opportunity. In the context of BioKIDS, however, she noticed possibilities for connecting camp with school activities.

They saw frogs and there were small things that were camouflaged in the woods and they were just maybe on walks or hikes or going from one program to the next and it was the young ones that were spotting things. So you see it might be interesting to see if we can take the CyberTracker with us. [Means, Technology, CyberTracker]

While the use of CyberTracker to collect data at the camp was interesting to her, she was particularly interested in having students use their camp data to contrast schoolyard data to emphasize the differences in biodiversity. 
In addition, Ms. Brooks augmented the first curricular activity by having students develop a schoolyard map in conjunction with the mathematics teacher, Ms. Dunn. Students spent the first day measuring the perimeter of the schoolyard and the remainder of the week in the classroom adding detail, color, and scale to their map.

In the schoolyard maps, Ms. Dunn put particular emphasis on scale, as this topic was covered in the MEAP. The next 3 days, the class spent outside measuring the schoolyard with a trundle wheel (day 1), determining appropriate scale, and completing the schoolyard map (days 2 and 3). Students worked in groups of four to complete one map per group. Ms. Brooks used the mapping exercise to set the frame for the remaining learning on biodiversity.

In week 3, when schoolyard maps are completed, Ms. Brooks opened class by reorienting students to the map and its relationship to the schoolyard. She divided the schoolyard into zones $\mathrm{A}-\mathrm{E}$ and assigned a student group to each zone.

We need to divide up our schoolyard into zones then we need to assign zones to each group and we need to go outside and start collecting some data for our zones. So that we have a little better idea of what our school looks like, what that school map looks like, we need to sort of section it off or look at it in terms of how is each group going to collect data from one particular area in our schoolyard. [Focus, Inquiry, Data Collection; Means, Inscription, Map]

After dividing the schoolyards into zones, Ms. Brooks asked students to go outside in their groups and make some observations while sitting silently and listening:

OK so our job is to go into our zones... you're go into your zone and I'll call time then you'll close your eyes for two minutes and I'll watch my second hand and then I'll call time again and you'll open your eyes and we're going to come back into the building to write down our observations. [Focus, Inquiry, Observation]

After silent observation, students followed a worksheet designed to help them collect data on the habitats in their zone.

The following day students prepared for field data collection. Ms. Brooks walked them through the activity with emphasis on the roles the students take for during schoolyard habitat data collection: "OK so it's telling you about all the different things, all the responsibilities you have as a field biologist" [Authentic, Process].

Reflecting on this activity, Ms. Brooks compared an investigation from the recommended textbook for sixth-grade science and the biodiversity investigation in BioKIDS: “... sometimes I don't see how some of the investigations. . . in their textbooks actually are teaching the concept" [Focus, Content].

Students used the PDAs with CyberTracker to collect data during their camp field trip into a rural region north of the city. When students returned from camp, they began the use of CyberTracker in their data collection on animals in their schoolyard. Schoolyard data were considerably different from the data collected at camp, as the camp data were significantly more biodiverse than the schoolyard. Ms. Brooks was specifically interested in student comparisons of camp and schoolyard data relative to biodiversity:

All right, we're changing gears a little bit here but since you went to camp with us you had an opportunity to use the Palm Pilots and the CyberTracker program and we have that data and what we thought we'd do today, since we have the whole group, is use the CyberTracker, the Palm Pilots to go outside and have you collect some data in your [schoolyard] zones so that we can come back and take a closer look at the two different habitats. [Means, Technology, CyberTracker; Focus, Inquiry, Inference] 
Outside in the schoolyard, Ms. Brooks emphasized the function of the data they were collecting as evidence: "OK so now we're looking for evidence remember and it's going to ask you how you saw your evidence" [Focus, Inquiry, Evidence].

Ms. Brooks also saw data collection as a foundation for representations that provide information for analysis comparing schoolyard biodiversity. Her emphasis on movement from observation, to data collection, to data representation, to evidence-based claims is reflected in the task she asked students to complete at the end of the unit.

The final activity of the unit-involved analysis of schoolyard data to determine which zone was most biodiverse. The students received spreadsheets with the data they collected using the CyberTracker software. Ms. Brooks moved the students through the activity of representing their data in graphs and then making claims about the biodiversity of the zones:

So our class hypothesis-[starts reading from a BioKIDS worksheet] using the habitat data that your class collected for each zone, determine which zone you think will have the highest biodiversity of animals. Think about which zone offers homes for the largest number of animals or abundance and the greatest number of types of animals, which is richness [done reading]. So take a minute there with your group to make that hypothesis and give two reasons why you made that choice. [Focus, Inquiry, Inference]

The next step in the activity asked students to create data tables by transferring data from the summary sheets onto worksheets that are part of the BioKIDS curriculum. Students then graph the data and begin to think about the conclusions the data will support.

OK so what we're going to do is take the information from our data summary reports and we're going to put together a data table. [Means, Inscription, Table]

Here's our data table, but we need to use our summary reports to get our information for those tables then we can use the information from our tables to make some graphs. [Means, Inscription, Graph]

When students are asked to support their claim about which zone is the most biodiverse with their data, Ms. Brooks returned them to the definition of biodiversity and reminded students their claims should take two key features into account: animal richness and abundance (key indicators of biodiversity). The claims the students made are all grounded in the data from the field. In Ms. Brooks's class, the students' study of biodiversity is organized around CyberTracker data they collected themselves in multiple zones in their schoolyard and beyond.

Ms. Brooks's enactment is characterized by a focus on student-collected data, both at camp and in their schoolyard, as well as students using these data to form scientific representations, claims, and explanations. Ms. Brooks focused student activities on determining which area had the greatest biodiversity (a scientific question), as well as systematic data collection to address their question. Ms. Brooks's students used technology tools in ways analogous to scientists' use in the field (CyberTracker is a tool used by field biologists). In another parallel to science practice, the intention of the students' data representations, their graphs of CyberTracker data, were used as public artifacts available for interpretation by other student groups.

Teachers' enactment of technology-rich, inquiry-fostering curricular is often considered in terms of their fidelity to the curricular materials. However, we choose to view the differences between materials and enactment as theoretically interesting and helpful in understanding the practice of inquiry science teaching in real classrooms. The two vignettes provide a sense of the development of each individual teacher's enactment of BioKIDS. It is a pattern of pedagogical choices made by a teacher over time, which allows for theoretical 
characterization of practice. Having two cases that are substantively different helps to throw the differences into higher relief so larger analytical patterns can be extracted. The enactment differences provide an empirical foundation for elements of a theory of inquiry science teaching grounded in practice. In the final section of the paper, we describe in detail the larger theoretical elements these patterns of practice represent.

\section{CONTRIBUTIONS TO A THEORY OF TEACHING}

Enacting classroom inquiry science is a challenge for teachers (Davis, 2003), not simply because it requires rethinking teachers' role in the classroom and reimagining their personal pedagogy. In addition, teachers must interpret the learning goals of the curricular designers in light of their beliefs and goals for their students. When teachers begin with identical materials, curricula develop differently in a classroom as a result of the emphasis, framing, and organization the teacher creates around the skeleton of activities. Often reform curricula in science emphasize or draw on idealized examples of how inquiry occurs in a classroom (Songer et al., 2003). Activities are created in this way to give teachers a "images of the possible" (Shulman, 1983, as cited by Borko, 2004, p. 5). However, such an idealized vision has the potential to convince teachers only of the impracticality of implementing inquiry pedagogy given the constraints of their local context. To address this conflict, we must have a clearer understanding of how enactment transforms curricular materials. The results of this study are an explication of theoretical elements of classroom practice that are more generalized than curricular activities and can lead to multiple exemplars of strong pedagogical enactment supported by standards. The elements of inquiry described below provide a potential contribution to a theory of pedagogy grounded in the act of teaching (Richardson, 2002), in this case, classroom inquiry science pedagogy.

\section{Elements of Inquiry}

The differences in the enactments of these two teachers are most easily framed in the form of elements developed analytically from the entire corpus of data. The elements of inquiry each encapsulate one dimension of the choices teachers make in enactment by describing a continuum of practice along this particular dimension. The students' experience is a direct result of the choices the teachers make and how those choices build to create the explicit and implicit goals of the enactment. By examining a teacher's curricular framing and organization as a larger pattern of practice, we can suggest elements of enactment that undergird the pattern. These elements are dimensions of enactment along which individual instantiations will fall. The forces, both external and internal, on teachers can be significant and how their enactment reaches equilibrium across an element defines not only the teacher's individual pedagogical approach and local constraints, but also their philosophy and beliefs.

In this study, two analytical elements of inquiry emerged as central to teachers' goals. We first discuss teachers' view of authenticity. The second element relates to teachers' difference in emphases in terms of the process skills of science. These elements describe analytical dimensions of enactment that illuminate the struggle teachers engage with while creating classroom communities of inquiry science learners. These dimensions also indicate that all choices have both affordances and trade-offs. No single vision of classroom inquiry science teaching can support student learning in all contexts, and thus teachers' choices define a panoply of instantiations of classroom inquiry science teaching. 


\section{Authenticity}

Authentic is a term used in science education literature almost as often as inquiry, and is equally contentious (e.g., Chinn \& Hmelo, 2002; Edelson, 1998; Means, 1998). The two critical cases in this study suggest teaching science has at least two dimensions of authenticity: authentic learning - the degree to which the teacher focuses enactment around students' pursuit of personally or locally relevant content; and authentic science-the degree to which the teacher focuses enactment on the development of students' understandings of and participation in the unique culture and practices of science. These two dimensions are often conflated by indicating that the degree of student control defines how authentic a given activity is, both in terms of learning and science (e.g., NRC, 2000, Figure 2.6).

In the first vignette, Mr. Denny's enactment focused more on his students' activity around authentic learning. Mr. Denny saw himself as a facilitator, allowing students more control of what content to engage with and how to represent their content understanding. He allowed students to organize into groups around species or families of organisms they were interested in investigating. He assisted students in formalizing their interests into a curricular structure, one tailored to individual students, their interests, and local context.

Mr. Denny's enactment was less focused on authentic science. His students wrote fieldnotes during visits to a local field site, and they collected specimens for identification. He said: "Today we are going to Riley Park for a BioKIDS experience. Riley Park is going to become like our lab, like you have a science lab upstairs." While his initial plan was to use these observations and specimens as data for determining the biodiversity of Riley Park, this did not occur. Mr. Denny's focus on his students' authentic learning resulted in the field biodiversity data collection morphing into less scientifically authentic versions of these tasks. Students' fieldnotes were more experiential or observational journals describing what they saw rather than a systematic attempt to gather evidence for answering a scientific question.

Another aspect of Mr. Denny's enactment was transformed by his choices and local constraints - the identification of specimens. Early on, Mr. Denny encouraged students to choose to pursue insects (difficult to identify specific species, but easy to find) instead of vertebrates (hard to find, but easier to identify by species). In addition, students' pursuit of interests in plants and fungi did not allow them to use the curricular technology tool designed to support field biodiversity data collection (CyberTracker) in a systematic way. These choices led to the identification of specimens to become less like authentic science. He encouraged one group: "Well I would suggest this, you have, you have some trees that you found, right? You could find information on those, on the Internet. You could look them up in a tree book." The activity students engaged in became more about general information gathering from online and library resources and collecting specimens for display.

Changes to the enactment based on the students' interests led to changes in the task students engaged in and resulted in a shift away from the scientific question Mr. Denny introduced in the beginning of the unit- "What is the biodiversity of Riley Park?" The final products from Mr. Denny's students reflect this shift away from authentic science and toward authentic learning. Students created reports or other artifacts which, for the most part, were not based directly on their field experience, but on information found in text and Web-based resources. One example of this can be seen as he read a student's proposed projects to the class: "I will pick seven spiders. I will study each of them and then write the basic information about them." No student used their fieldnotes as part of their final report and while some used specimens from the field (e.g., the tree identification guide), these reports were informational based on classroom resources. All of this leads to the clear conclusion that Mr. Denny's interpretation of the BioKIDS curriculum exemplified foregrounding authentic learning and a backgrounding of authentic science. 
In the second vignette, Ms. Brooks's enactment emphasized authentic science. In Ms. Brooks's class, students were engaged in the practices of science including using the tools, techniques, and methods commonly used by scientists with similar biodiversity questions. She regularly returned the class to the scientific question they were investigating - "Which zone in my schoolyard is most biodiverse?" She asked students to collect data systematically (using CyberTracker), share that data with peers, make representations of their data, and make evidence-based arguments drawing on these representations. She laid out for the students how they would organize the study:

So that we have a little better idea of what our school looks like, what that school map looks like, we need to sort of section it off or look at it in terms of how is each group going to collect data from one particular area in our schoolyard.

However, Ms. Brooks's enactment was less an example of authentic learning.

Ms. Brooks determined the content, approach, and final products for her students. Students' use of the CyberTracker software for field biodiversity data collection defined the types of organisms and data students would collect. Students all collected data on the same set of species, used scaffolded worksheets to build evidence-based arguments around the same question, and produced final artifacts that were identical in structure. She described the final activity to students:

So our class hypothesis-[starts reading from a BioKIDS worksheet] using the habitat data that your class collected for each zone, determine which zone you think will have the highest bio-diversity of animals. Think about which zone offers homes for the largest number of animals or abundance and the greatest number of types of animals, which is richness [done reading]. So take a minute there with your group to make that hypothesis and give two reasons why you made that choice.

Students had little, if any, input into the content or structure of the enactment.

Ms. Brooks made efforts to connect the enactment to her students' lives. She added an activity at the beginning of the unit to attempt to connect to a local issue of concern, brownfields, in an effort to make the learning more authentic. She also included data students collected during their camp experience to create a more authentic context for their data collection. In terms of the overall amount of student control over the enactment and content, however, Ms. Brooks's enactment foregrounded authentic science and backgrounded authentic learning.

The contrast of these two cases allows for a reconsideration of the concept of authenticity in science teaching. Authenticity can be seen to have (at least) two dimensions in tension with each other, where foregrounding one results in the backgrounding of the other. The teacher, in an interpretive act, takes curricula materials and makes choices about what will be foregrounded and backgrounded. These choices are a reflection of aspects of the teacher (e.g., content knowledge, beliefs about learning, and so on), the students, and the local context and constraints. Ultimately, choices about emphasis across these dimensions of authenticity lead to significantly different enactments of the same curricular materials.

The enactments of BioKIDS by Mr. Denny and Ms. Brooks are particularly useful cases as they represent the two quadrants in Figure 2 often implicitly ignored in science education literature. Their cases can provide a sense of how to think beyond one idealized standard for classroom inquiry science teaching (Songer et al., 2003). We believe conflation of the two aspects of authenticity leads to attending to only one diagonal-moving from less authentic in terms of both aspects of authenticity (lower left) to more authentic in terms of both 


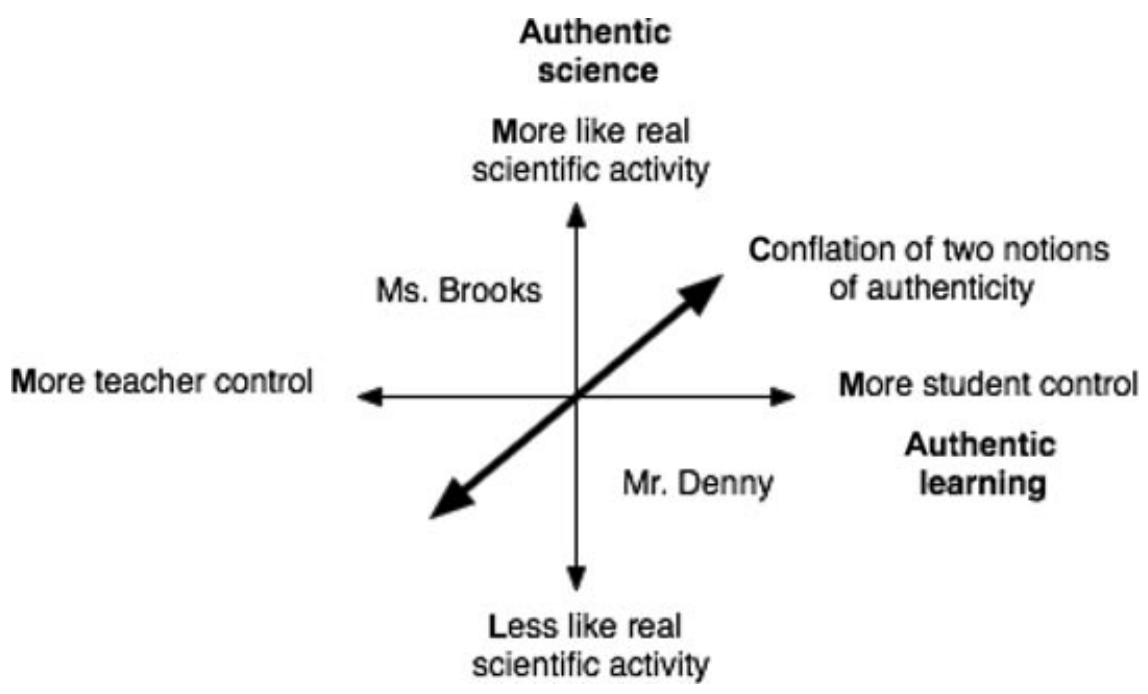

Figure 2. Enacting inquiry-authenticity.

(upper right), largely ignoring or dismissing the other quadrants of enactment. This is not to imply that a classroom enactment cannot engage students in the activities of science built on the interests of students. There are choices to be made, however, and local constraints, teachers' knowledge and beliefs, and a host of other factors mean that there are almost always trade-offs that must be made.

The transformation of curricular materials by teachers into classroom enactment defined by their choices, within local constraints, implicitly defines a place on both the continua of authentic learning and the continua of authentic science. These differences in authenticity reflect Dewey's (1902) discussion of the difference between student- and content-centered curricula. This study indicates this difference in curricular focus has a particular character in the case of science education, and also the differences have significant impact on the transformation of curricular materials during enactment of inquiry-fostering science curricula. The enactment of the BioKIDS curriculum in their two classrooms exemplifies different aspects of the tools and discourses of science.

\section{Descriptive Science and Inferential Science}

Mr. Denny's enactment reflects the skills of natural history with emphasis on observations, drawings, and specimen collection. In contrast, Ms. Brooks's enactment reflects the skills of natural science with an emphasis on collecting quantified data for analysis and comparison, creating representations of their data (inscriptions), and building an argument or claim supported by data. An enactment focusing on natural history is differentiated from one focusing on natural science primarily by differences in the intent and focus on different skills within the activities. Superficially, Mr. Denny's and Ms. Brooks's classes were engaged in many of the same activities - collecting data about the organisms in their local area and reporting that information. In detail, however, the differences in emphases led to enactment differences that cut across almost every activity the students engaged in or artifact they produced-field notebooks versus technology-based data collection, informational versus inferential reports, and field guides versus tentative answers to scientific questions. 
The fundamental difference in emphasis between natural history and natural science is that one foregrounds description, observation, identification, and organization, whereas the other foregrounds questions, hypotheses, data collection, inference, and analysis. Mr. Denny encouraged his class to "... when you find an insect. . . take some notes about its environment. Where do you find it? On the ground? On the tree? Maybe what kind of tree. Under debris, in the sunshine, OK." In contrast, Ms. Brooks told her students:

... since you went to camp with us you had an opportunity to use the Palm Pilots and the CyberTracker program and we have that data and what we thought we'd do today. .. is use the CyberTracker, the Palm Pilots to go outside and have you collect some data in your [schoolyard] zones so that we can come back and take a closer look at the two different habitats.

A teacher makes choices about which of these emphases best suits the content as well as their philosophy, local context, and constraints. The choice, as can be seen in the two critical cases, can have significant implications not only for the process skills students engage in but also the scientific content they are exposed to. Understanding these elements of classroom inquiry science teaching is critical to supporting teachers in enacting complex inquiryfostering curricula in their schools. Understanding how students develop these scientific skills over time is particularly critical. This study suggests that developing a specific learning progression (NRC, 2007) for the development of an integrated understanding of natural history and natural science process skills would contribute to teachers' enactment of inquiry science curricula in all grade levels.

The analytical tension between natural history and natural science emerging from these two teachers' enactment points to a larger pattern in science teaching and learning. Elementary school teachers struggle with teaching science and particularly with inquiry science (Arora, Kean, \& Anthony, 2000; Crawford, 2000; Zembal-Saul, Blumenfeld, \& Krajcik, 2000). Elementary school science tends to be more focused on natural history, usually to the exclusion of the analysis processes fundamental to natural science. For elementary-age students, curricula often emphasize observation and identification in large part based on Piagetian and neo-Piagetian views of children's development (Metz, 1995, 2000).

Secondary schools reverse this emphasis with a focus on science abstracted away from phenomenon in nature. Physics classes for high school students can become about learning heuristics for solving mathematical problems, which because of their idealizations, tend to disagree with observed reality. There is often little regard for developing an intuitive sense of physical phenomenon, and differences between theoretical values and experimental findings are glossed over. When students engage in hands-on activities, they are likely to be scripted and may even reinforce a heuristic or right answer epistemology of science (Chinn $\&$ Malhotra, 2002). Teaching students systematic ways of solving sets of similar problems is done in the name of preparing students for college classes, where science is often further abstracted from real-world applications.

The National Science Education Standards (NRC, 1996) call for science inquiry across grade levels; however, as this study illustrates, teachers can interpret this idea in quite different ways, even when following the same curricula. We suggest that our work provides implication for rethinking the common extremes in elementary and high school science. In particular, this study suggests the critical value of having a clear learning progression related to the development of observational and analytical skills across grade levels. Students in elementary school need to engage in data collection and analytical thinking to gain insight about their observations. While observation may still play a major role in early science experiences, observation should be reframed as a critical and early stage of a larger process that includes scientific reasoning. 
In secondary school, more attention needs to be paid to contextualizing science content in real-world phenomenon. While it may be that the majority of high school science is analytical, abstract concepts should be framed in real-world experience. With contextualizing the student's activity in observations of phenomenon, there is a loss not just of understanding of the content, but of the nature of scientific endeavor and knowledge.

\section{CONCLUSIONS}

This study contributes to research on classroom enactment by shedding light on enactment features from contrasting cases, particularly authentic learning-authentic science, and natural history-natural science. Only through a more detailed view of the nuances of interpretation and enactment of curricula by teachers can individuals begin to build an understanding of best means to support productive enactment of classroom inquiry science teaching. This study contributes to a theory of science teaching grounded in the act of teaching. An analytical understanding of the tensions in teacher enactment can help researchers and designers support teachers as they take ownership of pedagogical reforms in their classrooms and work with researchers to create a balanced fit between reform and the local context.

\section{APPENDIX}

\begin{tabular}{|c|c|c|}
\hline Code & Name & Definition \\
\hline AthnLocal & $\begin{array}{l}\text { Authentic, } \\
\text { Local site }\end{array}$ & $\begin{array}{l}\text { A goal to connect student learning to the local } \\
\text { context (either the schoolyard, study site, or } \\
\text { community). }\end{array}$ \\
\hline AthnOut & $\begin{array}{l}\text { Authentic, } \\
\text { Outcome }\end{array}$ & $\begin{array}{l}\text { A goal to set up an outcome(s) the teacher } \\
\text { believes is authentic to the content, student } \\
\text { interests, or to learning in general. }\end{array}$ \\
\hline AthnPrcs & $\begin{array}{l}\text { Authentic, } \\
\text { Process }\end{array}$ & $\begin{array}{l}\text { A goal to make what students are doing "like } \\
\text { what scientists do." }\end{array}$ \\
\hline CnstStdTest & $\begin{array}{l}\text { Constraint, } \\
\text { Standardized tests }\end{array}$ & $\begin{array}{l}\text { A constraint originating in a need to align goals } \\
\text { with a standardized test. }\end{array}$ \\
\hline FcsCnt & $\begin{array}{l}\text { Focus, } \\
\text { Content }\end{array}$ & A goal choice focused on a content outcome. \\
\hline FcsInqColl & $\begin{array}{l}\text { Focus, } \\
\text { Inquiry skill, } \\
\text { Data collection }\end{array}$ & $\begin{array}{l}\text { A goal choice focused the inquiry skill of data } \\
\text { collection. }\end{array}$ \\
\hline FcsInqIden & $\begin{array}{l}\text { Focus, } \\
\text { Inquiry skill, } \\
\text { Identify }\end{array}$ & $\begin{array}{l}\text { A goal choice focused the inquiry skill of } \\
\text { identifying or naming organisms. }\end{array}$ \\
\hline FcsInqInfer & $\begin{array}{l}\text { Focus, } \\
\text { Inquiry skill, } \\
\text { Inference }\end{array}$ & $\begin{array}{l}\text { A goal choice focused the inquiry skill of } \\
\text { drawing inferences from data. }\end{array}$ \\
\hline FcsInqObs & $\begin{array}{l}\text { Focus, } \\
\text { Inquiry skill, } \\
\text { Observation }\end{array}$ & $\begin{array}{l}\text { A goal choice focused the inquiry skill of } \\
\text { making observations (without necessarily } \\
\text { collecting data). }\end{array}$ \\
\hline
\end{tabular}




\begin{tabular}{|c|c|c|}
\hline MnsInscFldnt & $\begin{array}{l}\text { Means, } \\
\text { Inscription, } \\
\text { Fieldnotes }\end{array}$ & $\begin{array}{l}\text { Use of fieldnotes as a means of engaging } \\
\text { students with a goal }\end{array}$ \\
\hline MnsInscGraph & $\begin{array}{l}\text { Means, } \\
\text { Inscription, } \\
\text { Graph }\end{array}$ & $\begin{array}{l}\text { Use of a graph of data the students have } \\
\text { gathered as a means of engaging students } \\
\text { with a goal. }\end{array}$ \\
\hline MnsInscMap & $\begin{array}{l}\text { Means, } \\
\text { Inscription, } \\
\text { Map }\end{array}$ & $\begin{array}{l}\text { Use of a map as a means of engaging students } \\
\text { with a goal. }\end{array}$ \\
\hline MnsInscReport & $\begin{array}{l}\text { Means, } \\
\text { Inscription, } \\
\text { Report }\end{array}$ & $\begin{array}{l}\text { Use of a report based on information the student } \\
\text { has collected and organized from resources as } \\
\text { a means of engaging students with a goal. }\end{array}$ \\
\hline MnsTechCC & $\begin{array}{l}\text { Means, } \\
\text { Technology, } \\
\text { Critter Catalog }\end{array}$ & $\begin{array}{l}\text { Use of the Critter Catalog to support engaging } \\
\text { students with a goal. }\end{array}$ \\
\hline MnsTechCT & $\begin{array}{l}\text { Means, } \\
\text { Technology, } \\
\text { CyberTracker }\end{array}$ & $\begin{array}{l}\text { Use of CyberTracker to support engaging } \\
\text { students with a goal. }\end{array}$ \\
\hline
\end{tabular}

\section{REFERENCES}

Abd-El-Khalick, F., BouJaoude, S., Duschl, R. A., Lederman, N. G., Mamlok-Naaman, R., Hofstein, A., et al. (2004). Inquiry in science education: International perspectives. Science Education, 88, 397-419.

American Association for the Advancement of Science. (1993). Benchmarks for science literacy. New York: Oxford University Press.

Arora, A. G., Kean, E., \& Anthony, J. L. (2000). An interpretive study of a teachers' evolving practice of elementary school science. Journal of Science Teacher Education, 11(2), 155-172.

Ball, D. L., \& Bass, H. (2000). Making believe: The collective construction of public mathematical knowledge in the elementary classroom. In D. C. Phillips (Ed.), Constructivism in education: Opinions and second opinions on controversial issues (Vol. 99, Part 1, pp. 193-223). Chicago: The University of Chicago Press.

Bell, P., \& Linn, M. C. (2000). Scientific arguments as learning artifacts: Designing for learning from the web with KIE. International Journal of Science Education, 22(8), 797-817.

Blumenfeld, P. C., Fishman, B. J., Krajcik, J. S., Marx, R. W., \& Soloway, E. (2000). Creating useable innovations in systemic reform: Scaling up technology-embedded project-based science in urban schools. Educational Psychologist, 35(3), 149-164.

Borko, H. (2004). Professional development and teacher learning: Mapping the terrain. Educational Researcher, 33(8), 3-15.

Brown, A. L., Ash, D., Rutherford, M., Nakagawa, K., Gordon, A., \& Campione, J. C. (1993). Distributed expertise in the classroom. In G. Salomon (Ed.), Distributed cognitions: Psychological and educational considerations (pp. 188-228). Cambridge, England: Cambridge University Press.

Chinn, C. A., \& Hmelo, C. E. (2002). Authentic inquiry: Introduction to the special section. Science Education, 86, 171-174.

Chinn, C. A., \& Malhotra, B. A. (2002). Epistemologically authentic inquiry in schools: A theoretical framework for evaluating inquiry tasks. Science Education, 86, 175-218.

Cobb, P., McClain, K., Lamberg, T. D. S., \& Dean, C. (2003). Situating teachers' instructional practices in the institutional setting of the school and district. Educational Researcher, 32(6), 13-24.

Cobb, P., Stephan, M., McClain, K., \& Gravemeijer, K. (2001). Participating in classroom mathematical practices. Journal of the Learning Sciences, 10(1 and 2), 113-163.

Combs, A. W. (1991). The schools we need: New assumptions for educational reform. Lanham, MA: University Press of America.

Crawford, B. A. (2000). Embracing the essence of inquiry: New roles for science teachers. Journal of Research in Science Teaching, 37(9), 916-937. 
Davis, K. S. (2003). "Change is hard": What science teachers are telling us about reform and teacher learning of innovative practices. Science Education, 87, 3-30.

Dewey, J. (1902). The child and the curriculum (Vol. 5). Chicago: The University of Chicago Press.

Dewey, T. A., Hammond, G. S., Espinosa, R., Parr, C. S., \& Jones, T. (2005). BioKIDS Critter Catalog (online). Retrieved September 25, 2005, from http://www.biokids.umich.edu.

Edelson, D. C. (1998). Realizing authentic science learning through the adaptation of science practice. In B. J. Fraser \& K. G. Tobin (Eds.), International handbook of science education (pp. 317-331). London: Kluwer Academic Publishers.

Edelson, D. C., Gordin, D. N., \& Pea, R. D. (1999). Addressing the challenges of inquiry-based learning through technology and curriculum design. Journal of the Learning Sciences, 8(3 and 4), 391-450.

Gravemeijer, K., \& Cobb, P. (2006). Design research from a learning design perspective. In J. van den Akker, K. Gravemeijer, S. McKenney, \& N. Nieveen (Eds.), Educational design research (pp. 17-51). Abingdon, Oxon, England: Routledge.

Keys, C. W., \& Bryan, L. A. (2001). Co-constructing inquiry-based science with teachers: Essential research for lasting reform. Journal of Research in Science Teaching, 38(6), 631-645.

Krajcik, J. S., Blumenfeld, P. C., Marx, R. W., Bass, K. M., Fredricks, J., \& Soloway, E. (1998). Inquiry in project-based science classrooms: Initial attempts by middle school students. Journal of the Learning Sciences, 7(3 and 4), 313-350.

Lave, J., \& Wenger, E. (1991). Situated learning: Legitimate peripheral participation. Cambridge, England: Cambridge University Press.

Lee, H.-S., \& Songer, N. B. (2003). Making authentic science accessible to students. International Journal of Science Education, 25(8), 923-948.

McClain, K. (2002). Teacher's and students' understanding: The role of tools and inscriptions in supporting effective communication. Journal of the Learning Sciences, 11(2 and 3), 217-249.

Means, B. (1998). Melding authentic science, technology, and inquiry-based teaching: Experiences of the globe program. Journal of Science Education and Technology, 7(1), 97-105.

Metz, K. E. (1995). Reassessment of developmental constraints on children's science instruction. Review of Educational Research, 65(2), 93-127.

Metz, K. E. (2000). Young children's inquiry in biology: Building the knowledge bases to empower independent inquiry. In J. Minstrell \& E. van Zee (Eds.), Inquiring into inquiry learning and teaching in science (pp. 371-404). Washington, DC: American Association for the Advancement of Science.

Miles, M. B., \& Huberman, A. M. (1984). Qualitative data analysis: A sourcebook of new methods. Beverly Hills, CA: Sage.

Moschkovich, J., \& Brenner, M. E. (2000). Integrating a naturalistic paradigm into research on mathematics and science cognition and learning. In A. E. Kelly \& R. A. Lesh (Eds.), Handbook of research design in mathematics and science education (pp. 457-486). Mahwah, NJ: Erlbaum.

National Research Council. (1996). National Science Education Standards. Washington, DC: National Academy Press.

National Research Council. (2000). Inquiry and the National Science Education Standards. Washington, DC: Author.

National Research Council. (2007). Taking science to the schools: Learning and teaching science in grades K-8. Washington, DC: National Academy Press.

Palinscar, A. S. (1998). Social constructivist perspectives on teaching and learning. Annual Review of Psychology, 49, 345-375.

Palinscar, A. S., Magnusson, S. J., Marano, N. L., Ford, D., \& Brown, N. (1998). Designing a community of practice: Principles and practices from the GISML community. Teaching and Teacher Education, 14(1), 5-19.

Pea, R. D. (1993). Practices of distributed intelligences and design for education. In G. Solomon (Ed.), Distributed cognitions: Psychological and educational considerations (pp. 47-87). Cambridge, England: Cambridge University Press.

Polman, J. L. (2000). Designing project-based science: Connecting learners through guided inquiry. New York: Teachers College Press.

Putnam, R. T., \& Borko, H. (2000). What do new views of knowledge and thinking have to say about research on teacher learning? Educational Researcher, 29(1), 4-13.

Reiser, B. J., Tabak, I., Sandoval, W. A., Smith, B. K., Steinmuller, F., \& Leone, A. J. (2001). BUGILE: Strategic and conceptual scaffolds for scientific inquiry in biology classrooms. In S. Carver \& D. Klahr (Eds.), Cognition and instruction: Twenty-five years of progress (pp. 263-305). Mahwah, NJ: Erlbaum.

Richardson, V. (2002). Finding a center for research on teaching. Paper presented at the Annual Meeting of the American Educational Research Association (AERA), New Orleans, LA. 
Roth, W.-M. (1995). Authentic school science: Knowing and learning in open-inquiry science laboratories. Dordrecht, the Netherlands: Kluwer.

Roth, W.-M., \& Lawless, D. (2002). Science, culture, and the emergence of language. Science Education, 86, 368-385.

Songer, N. B. (1996). Exploring learning opportunities in coordinated network-enhanced classrooms: A case of kids as global scientists. Journal of the Learning Sciences, 5(4), 297-327.

Songer, N. B. (2006) BioKIDS: An animated conversation on the development of complex reasoning in science. In R. Keith Sawyer (Ed.) Cambridge handbook of the learning sciences (pp. 355-369). New York: Cambridge University Press.

Songer, N. B., Lee, H. S., \& Kam, R. (2002). Technology-rich inquiry science in urban classrooms: What are the barriers to inquiry pedagogy? Journal of Research in Science Teaching, 39(2), 128-150.

Songer, N. B., Lee, H. S., \& McDonald, S. (2003). Research towards an expanded understanding of inquiry science beyond one idealized standard. Science Education, 87, 490-516.

Tabak, I. (2002). Teacher as monitor, mentor or partner: Uncovering participant structures involved in supporting student-directed inquiry. Paper presented at the International Conference of the Learning Sciences (ICLS), Seattle, WA.

Vygotsky, L. (1978). Mind in society: The development of higher psychological processes. M. Cole, V. JohnSteiner, S. Scribner, \& E. Souberman (Trans.). Cambridge, MA: Harvard University Press.

Zembal-Saul, C., Blumenfeld, P. C., \& Krajcik, J. S. (2000). Influence of guided cycles of planning, teaching, and reflection on prospective elementary teachers' science content representations. Journal of Research in Science Teaching, 37(4), 318-339. 